\title{
Experimental studies of sediment reworking and growth of Scoloplos spp. (Orbiniidae: Polychaeta)
}

\author{
Donald L. Rice*, Thomas S. Bianchi* \& Edward H. Roper \\ Department of Geological Sciences \& Environmental Studies, State University of New York, Binghamton, New York 13901,
} USA

\begin{abstract}
Surface biodeposition of organic carbon and total sediment from the conveyor-belt feeding activity of Scoloplos spp. were monitored concomitantly with worm growth in experimental microcosms. At constant temperature and under conditions where available particle size did not limit ingestion, particle reworking rate was proportional to worm biomass. If competition between individuals for particles of preferred size is intense, Scoloplos may adjust its size selectivity to meet physiological maintenance requirements. Scoloplos assimilated organic carbon from its native sediments from Lowes Cove, Maine, with an efficiency of about $24 \%$. Gross growth efficiencies based on total and metabolizable particulate organic carbon were 2.4 and $8.3 \%$ respectively. Based on total and metabolizable particulate organic nitrogen gross growth efficiencies were 4 and $63 \%$ respectively. Incorporating the results of other nutritional studies, we estimate that approximately $4 \%$ of the total nitrogen in an experimental sediment from Flax Pond, New York, was nutritionally available to these worms. Microbes may account for most of the organic nitrogen required by Scoloplos, although most of the organic carbon (i.e. caloric) requirement must be met by utilizing organic detritus.
\end{abstract}

\section{INTRODUCTION}

Macroinvertebrates that ingest particles at depth and egest them upon the sediment surface - the 'conveyor-belt species' of Rhoads (1974) - are major agents of sediment reworking in many benthic communities. Although they may be found in earlier successional stages, conveyor-belt deposit-feeders are characteristic members of equilibrium stage benthic communities (Rhoads \& Boyer 1982). These animals commonly feed in the vicinity of the redox potential discontinuity (RPD) and may have major impacts upon microbial distribution and activity at the top and bottom of the conveyor-belt (Rhoads 1974, Hylleberg 1975, Yingst \& Rhoads 1980, Dobbs \& Whitlatch 1982). Moreover, the relatively rapid ejection of reduced substances to the sediment surface and relatively slow return flow to depth is of special significance in the early diagenesis of redox sensitive substances such as organic matter and transition metals (Rhoads 1974, Rice \& Whitlow $1985 \mathrm{a}, \mathrm{b})$. Nevertheless, the relations between the nu-

\footnotetext{
- Present address: Chesapeake Biological Laboratory, Center for Environmental and Estuarine Studies, University of Maryland, Solomons, Maryland 20688 USA
}

trition of conveyor-belt feeders and the composition of the sedimentary milieu is poorly understood (Cammen 1980a, Whitlatch \& Weinberg 1982) and presents an especially difficult challenge to benthic investigators (Lopez \& Levinton in Press).

In the sediments of Lowes Cove, an intertidal mudflat on the coast of Maine, orbiniid polychaetes of the genus Scoloplos feed in the conveyor-belt mode and appear to be responsible for most vertical mixing of particles in the top several centimeters (Rice 1986). Properties of Lowes Cove sediments such as organic content, porosity, and trace metal chemistry are uniquely related to the abundance of Scoloplos (Rice \& Whitlow $1985 \mathrm{a}, \mathrm{b})$. Consequently some understanding of the feeding ecology of these polychaetes and their impact on sediment reworking is needed.

In this paper we report the results of 2 laboratory studies of particle ingestion/egestion rates, particle selectivity, and growth of Scoloplos. The first experiment followed biodeposition rates and organic content of biodeposits of growing worms cultured in an essentially infinite field of ingestible particles derived from native sediments. In the second, biodeposition and growth were monitored in cultures in which competition between individuals was induced by varying 
worm abundance and by using an exotic sediment containing a significantly lower proportion of particles of ingestible size. In addition to providing basic information on rates of reworking, these observations allowed us to assess the applicability of 2 theories of foraging strategy and to estimate the detrital maintenance rations for these deposit-feeders.

\section{MATERIALS AND METHODS}

Preparation of experimental animals and sediments. Scoloplos spp. from Lowes Cove, Maine, were cultured in a mixture of sediments from Lowes Cove and Flax Pond, Long Island, New York, in a recirculating seawater aquarium for 6 to 10 mo before experiments were begun. Four species of this genus $-S$. robustus, $S$. acutus, $S$. fragilis, and $S$, armiger - have been identified in Lowes Cove (A. Hillyard \& L. Walting, pers. comm.) and might have been present in our stock culture. Based on examination of several random samples, S. robustus accounts for about $75 \%$ of all Scoloplos taken from Lowes Cove between 1981 and 1984, and about $85 \%$ of the individuals held in our aquarium stock culture; $S$. acutus and $S$. fragilis account for the remainder. These 3 species are morphologically similar, requiring chemical staining and microscopic examination of parapodial structure for positive identification. Because these species have similar morphologies and feeding habits and because they were usually destined for trace element assay, worms actually used in the experiments below were not identified to species level.

In laboratory aquaria, Scoloplos spp. form temporary burrows composed of a vertical shaft from the sediment surface to the region of the RPD. One or more feeding galleys, inclined somewhat from the horizontal, extend
2 to $4 \mathrm{~cm}$ from the base of the vertical shaft. Typically, the site of surface biodeposition may change several times a week as the worm forms extended burrows during migration. In culture, these worms appear to feed only when they are in the normal inverted position. When single worms (dry biomass ca $2 \mathrm{mg}$ ) are cultured in large batches of either of the experimental sediments described below, they ingest a size spectrum of particles similar to the ambient size spectrum of sedimentary particulates in the conveyor-belt zone of Lowes Cove (Table 1). A more detailed account of the ecology of these polychaetes with special reference to their relation to the benthic community of Lowes Cove has been given elsewhere (Rice 1986).

Two experimental sediments were prepared from near-surface sediment (topmost $10 \mathrm{~cm}$ ) from Lowes Cove and from Flax Pond. Erratic particles and macrofauna larger than $1000 \mu \mathrm{m}$ were removed by wet sieving. Lowes Cove sediment was sieved again to remove the abundant fauna larger than $500 \mu \mathrm{m}$, and the coarse fraction (500 to $1000 \mu \mathrm{m})$ was recombined with the finer fraction. After sieving, wet sediments were stored for several days and allowed to become thoroughly anoxic and to warm up to ambient laboratory temperature $\left(24\right.$ to $\left.26^{\circ} \mathrm{C}\right)$. This procedure produced 2 sediments free of interfering macrofauna but with entirely different particle size distributions (Table 1). The experimental sediment from Lowes Cove was a sandy clayey silt with a molar organic $C$ : N ratio of 10 ; the 2 larger size fractions contained recognizable particles of macroalgal detritus. Flax Pond sediment was a silty sand with a molar organic $C: N$ ratio of 13 ; Spartina alterniflora detritus was present in this sediment and probably accounted for the significantly higher organic content compared to the Lowes Cove material.

Biodeposition, particle selection, and worm growth in Lowes Cove sediment. Sixteen polypropylene mic-

Table 1. Particle size distribution and organic carbon-nitrogen characteristics of experimental sediments and particle size distributions in biodeposits of Scoloplos cultured in these sediments

\begin{tabular}{|c|c|c|c|c|c|c|c|c|}
\hline \multirow[t]{2}{*}{$\begin{array}{l}\text { Particle size } \\
\text { range }(\mu \mathrm{m})\end{array}$} & \multicolumn{3}{|c|}{ Lowes Cove sediment } & \multicolumn{3}{|c|}{ Flax Pond sediment } & \multicolumn{2}{|c|}{$\begin{array}{c}\text { Scoloplos }{ }^{\circ} \text { biodeposits } \\
\text { Particle size } \\
\text { distribution (weight \%) }\end{array}$} \\
\hline & $\begin{array}{l}\text { Size } \\
\text { distribution } \\
\text { (weight } \%)\end{array}$ & $\% \mathrm{C}^{\cdots}$ & $\% \mathrm{~N}^{\cdots}$ & $\begin{array}{l}\text { Size } \\
\text { distribution } \\
\text { (weight } \% \text { ) }\end{array}$ & $\% \mathrm{C}^{*}$ & $\% \mathrm{~N}^{*}$ & $\begin{array}{l}\text { In } \\
\text { Lowes Cove } \\
\text { sediment }\end{array}$ & $\begin{array}{l}\text { In } \\
\text { Flax Pond } \\
\text { sediment }\end{array}$ \\
\hline $1000-250$ & $5 \pm 2$ & $2.16 \pm 1.03$ & $0.28 \pm 0.11$ & $45 \pm 1$ & - & - & $2 \pm 2$ & 0 \\
\hline $250-63$ & $26 \pm 2$ & $0.32 \pm 0.04$ & $0.04 \pm 0.01$ & $35 \pm 1$ & \multirow{2}{*}{$3.52 \pm 0.16$} & \multirow{2}{*}{$0.32 \pm 0.02$} & $28 \pm 2$ & $28 \pm 2$ \\
\hline$<63$ & $69 \pm 3$ & $1.02 \pm 0.05 \cdots$ & $0.14 \pm 0.01$ & $20 \pm 1$ & & & $70 \pm 2$ & $72 \pm 2$ \\
\hline \multicolumn{9}{|c|}{$\begin{array}{l}\text { - Multiple determinations with worms of dry biomass } 1.6 \text { to } 2.2 \mathrm{mg} \text { ind }^{-1} \\
\ldots \text { Organic carbon determined by wet oxidation; nitrogen by Kjeldahl digestion } \\
\ldots \text { For Lowes Cove sediment }<44 \mu \mathrm{m} \text {, average } \% \text { organic } C=1.21 \pm 0.08 \%\end{array}$} \\
\hline
\end{tabular}


roaquaria ( $8 \mathrm{~cm}$ inner diameter $\mathrm{x} 6 \mathrm{~cm}$ depth) were filled to a depth of $5 \mathrm{~cm}$ with sieved, defaunated sediment from Lowes Cove. These microaquaria were submerged in a $700 \mathrm{l}$ recirculating seawater aquarium (regulated at $17 \pm 1^{\circ} \mathrm{C}, \quad 30 \pm 1 \%$ salinity, $\mathrm{pH}=8.1 \pm 0.05)$ for $7 \mathrm{~d}$ to develop an oxidized surface layer (ca $1.5 \mathrm{~cm}$ deep). One healthy Scoloplos $\left(1.0 \pm 0.1 \mathrm{mg}\right.$ dry biomass ind $\left.{ }^{-1}\right)$ from the stock culture was placed into a small depression in the sediment surface of each microaquarium and allowed to burrow. In 9 of the microaquaria, worms burrowed within $1 \mathrm{~d}$ and began feeding within $3 \mathrm{~d}$. Worms in the other 7 either did not burrow, burrowed and did not resume normal feeding activity, or escaped from the microaquarium and consequently were excluded from further experimentation.

Four d after inoculation, the feeding experiment was begun by manually leveling surface feeding mounds in the 9 active microaquaria. Every 4 d for a total of 16 d, surface deposits were collected with long stem pipets, placed into tared, pre-fired aluminum weighing pans, and washed with several ml of distilled water to remove sea salts. Washed biodeposits were dried for $16 \mathrm{~h}$ at $80^{\circ} \mathrm{C}$ and stored in a freezer. At the end of the experiment, biodeposits from all 4 sampling periods were dried further at $110^{\circ} \mathrm{C}$ until a constant weight was achieved. Average biodeposition rates ( $\mathrm{g}$ dry sediment ind $\mathrm{d}^{-1} \mathrm{~d}^{-1}$ ) were then calculated for each $4 \mathrm{~d}$ period. The dried material was then combusted at $550^{\circ} \mathrm{C}$ for $16 \mathrm{~h}$. Weight loss on ignition (WLOI) under these conditions was used to estimate particulate organic carbon content using the relation

$$
\% \mathrm{C}_{\text {organic }}=0.420 \times \% \mathrm{WLOI}
$$

(correlation coefficient $=0.97$, standard error of estimate $=0.08 \%$ carbon). This empirical relation yields highly reproducible results and is based on the comparison of WLOI and organic carbon (instrumental CHN analysis) determinations on 15 sediment samples from Lowes Cove. After the final collection on Day 16, worms were sieved from each microcosm (500 $\mu \mathrm{m}$ mesh), washed with seawater, and allowed to stand for $16 \mathrm{~h}$ in seawater to permit as much clearance of the gut as possible. Final individual dry biomasses were determined after lyophilization.

Biodeposition and growth in Flax Pond sediments. Eight microaquaria were prepared as above with Flax Pond sediment and submerged in the recirculating aquarium (regulated at $15 \pm 1{ }^{\circ} \mathrm{C}$; other conditions as above). To each of 2 microcosms, 2, 4, 8, or 15 worms $\left(2.05 \pm 0.17 \mathrm{mg}\right.$ dry weight ind $\left.^{-1}\right)$, representing 400 , 800,1600 , and 3000 ind $\mathrm{m}^{-2}$, were added. All burrowed and began feeding within $1 \mathrm{wk}$, although in the
2 highest-density systems worms would sometimes reemerge, move laterally, and burrow again.

The feeding experiment was conducted as described above except that the cultures were maintained for a total of $36 \mathrm{~d}$. Procedures for collection and treatment of biodeposits, determination of final worm biomasses, and calculations of average $4 \mathrm{~d}$ biodeposition rates were also as described above; however, \% WLOI and $\% \mathrm{C}$ were not determined.

For both experiments, uncertainties in raw data were propagated in all computations according to Bevington (1969). In this paper, statistical significance implies that the probability of the null hypothesis was less than 0.05 .

\section{RESULTS}

\section{Individual Scoloplos in Lowes Cove sediments}

At $17^{\circ} \mathrm{C}$, biodeposition rates of worms cultured in near-surface sediment from Lowes Cove increased from 64 to $112 \mathrm{mg}$ dry sediment ind ${ }^{-1} \mathrm{~d}^{-1}$ over the $16 \mathrm{~d}$ period, although rates per unit worm biomass did not change (Table 2). Average worm biomass increased from the initial value of $1.02 \pm 0.21$ to a final value of $1.74 \pm 0.30 \mathrm{mg}$ dry weight ind ${ }^{-1}$. Because both individual biodeposition rates and biomass increased by a factor of 1.74 , initial and final biodeposition rates per unit worm biomass were identical ( $64 \pm 25$ and $64 \pm 15$ mg dry sediment [mg worm] ${ }^{-1} \mathrm{~d}^{-1}$, respectively).

In Scoloplos biodeposits over the same $16 \mathrm{~d}$ period, $\%$ WLOI decreased from 3.0 to $1.5 \%$ and organic carbon decreased from 1.26 to $0.63 \%$. From Table 1 , for worms of similar size to those at the end of the experiment, the average organic carbon content of that fraction of Lowes Cove sediment selectively ingested was $0.83 \%$. Because smaller worms earlier in the experiment egested particulates with an organic carbon content substantially higher than $0.83 \%$ (Table 2 ), feeding initially must have been biased toward finer, organicrich particles smaller than $44 \mu \mathrm{m}$ (Table 1). This result is consistent with our casual observations that smaller individuals of this genus generally produce small feeding mounds of fine, powdery material, whereas larger individuals in the same sediment produce larger, coarser-grained mounds.

Because of the combined effects of increases in individual feeding rate and decreases in \% WLOI and \% C over time, biodeposition rates of combustible matter and organic carbon were not significantly different between sampling times (Table 2). However, on a worm weight-specific basis, the initial and final rates were significantly different $(0.80 \pm 0.37$ and $0.40 \pm 0.14 \mathrm{mg} \mathrm{C}[\mathrm{mg} \text { dry worm }]^{-1} \mathrm{~d}^{-1}$, respectively) 
Table 2. Surface biodeposition rate and total combustible material and organic carbon in biodeposits of Scoloplos in near-surface sediment from Lowes Cove, Maine. Worm biomasses and estimates of the rate of deposition of organic C per unit biomass are given for the first and last sampling times. Uncertainties are expressed as the standard deviation from the mean of 9 determinations. $\mathrm{T}=17 \pm 1^{\circ} \mathrm{C}$

\begin{tabular}{|c|c|c|c|c|}
\hline & \multicolumn{4}{|c|}{ Sampling period (d) } \\
\hline & $0-4$ & $4-8$ & $8-12$ & $12-16$ \\
\hline $\begin{array}{l}\text { Biodeposition rate } \\
\left(\text { mg dry sed. ind } d^{-1} \mathrm{~d}^{-1}\right)\end{array}$ & $64.2 \pm 25.2$ & $68.1 \pm 28.8$ & $78.6 \pm 35.2$ & $112.0 \pm 26.0$ \\
\hline $\begin{array}{l}\text { Combustible material } \\
\text { in surface deposits ( } \% \text { of dry weight) }\end{array}$ & $3.00 \pm 0.52$ & $2.29 \pm 0.45$ & $2.17 \pm 0.25$ & $1.51 \pm 0.27$ \\
\hline $\begin{array}{l}\text { Organic carbon } \\
\text { in surface deposits ( } \% \text { of dry weight) }\end{array}$ & $1.26 \pm 0.22$ & $0.96 \pm 0.19$ & $0.91 \pm 0.10$ & $0.63 \pm 0.11$ \\
\hline $\begin{array}{l}\text { Individual worm biomass } \\
\text { (mg dry wt. ind }{ }^{-1} \text { ) }\end{array}$ & $1.02 \pm 0.21$ & - & - & $1.74 \pm 0.30$ \\
\hline $\begin{array}{l}\text { Particulate organic } \mathrm{C} \\
\text { biodeposition rate } \\
\left(\mathrm{mg} C \mathrm{ind}^{-1} \mathrm{~d}^{-1}\right)\end{array}$ & $0.85 \pm 0.35$ & $0.65 \pm 0.30$ & $0.72 \pm 0.33$ & $0.71 \pm 0.20$ \\
\hline
\end{tabular}

\section{Scoloplos in Flax Pond sediments}

After $36 \mathrm{~d}$ of incubation in Flax Pond sediment, average individual worm biomass increased in the 400 and 800 ind $\mathrm{m}^{-2}$ microcosms and decreased in the 1600 and 3000 ind $\mathrm{m}^{-2}$ microcosms (Table 3, Fig. 1). At the end of the experiment, a large number of eggs were noted in 2 of the large worms in the 200 ind $\mathrm{m}^{-2}$ microcosms; no other gravid individuals were found.

At $15^{\circ} \mathrm{C}$, the rate of production of surface biodeposits in Flax Pond sediments varied with worm abundance and time (Table 4). Total surface deposition rates per microcosm initially were equal at the 3 lowest worm densities; within $24 \mathrm{~d}$ these rates increased steadily and leveled off at maximum values that were different but of similar magnitude (not proportional to either the number or biomass or worms per microcosm). Throughout the experiment, total surface deposition rate in the highest density treatment was 2.5 to 3 times greater than at the 3 lower densities. The total dry mass of surface biodeposits produced in $36 \mathrm{~d}$ was $36.5 \pm 1.2$ $g$ in the highest density treatment and $11.4 \pm 0.5$,

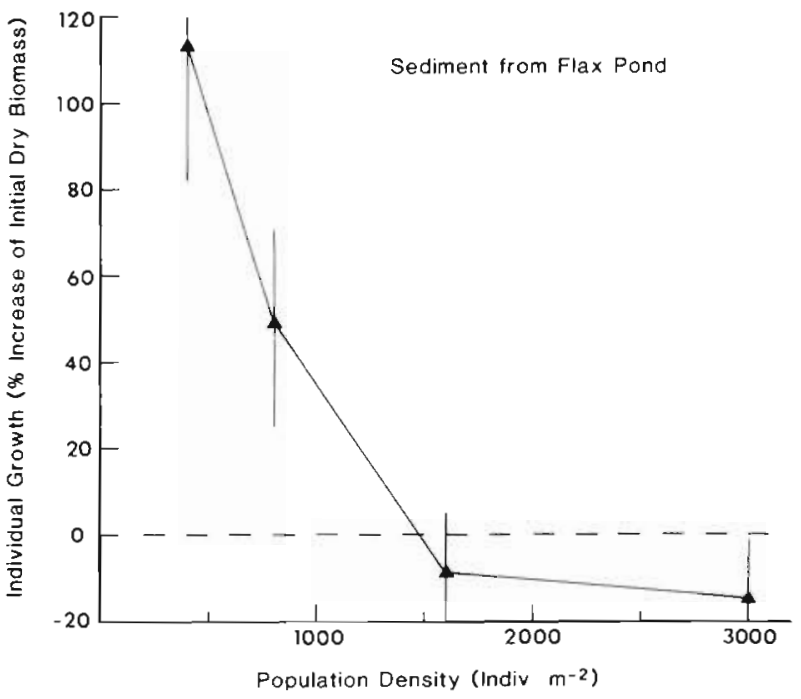

Fig. 1. Scoloplos spp. Average 36d individual growth of specimens cultured at 4 densities in sediments from Flax Pond, New York. Uncertainties are 1 SD from the mean of 4,8 , 16 and 30 individual determinations at the 4 respective worm densities. $\mathrm{T}=15 \pm 1^{\circ} \mathrm{C}$

Table 3. Final average individual biomass of Scoloplos grown in Flax Pond sediments and initial and final rates of surface biodesposition per unit biomass. $T=15 \pm 1{ }^{\circ} \mathrm{C}$. Initial biomass was $2.05 \mathrm{mg}$ dry weight ind ${ }^{-1}$

\begin{tabular}{|lccc|}
\hline $\begin{array}{l}\text { Worm abundance } \\
\left(\text { ind } \mathrm{m}^{-2}\right)\end{array}$ & $\begin{array}{c}\text { Final average } \\
\text { individual biomass } \\
\left(\mathrm{mg} \mathrm{dry} \text { wt ind }{ }^{-1}\right)\end{array}$ & $\begin{array}{c}\text { Biodeposition rate } \\
\left(\mathrm{g} \text { dry sediment }(\mathrm{g} \text { worm })^{-1} \mathrm{~d}^{-1}\right) \\
\text { Initial }(\mathrm{t}=0 \mathrm{~d})\end{array}$ \\
\hline 400 & $4.37 \pm 0.61$ & $46 \pm 15$ & $45 \pm 6$ \\
800 & $3.04 \pm 0.45$ & $22 \pm 12$ & $34 \pm 3$ \\
1600 & $1.87 \pm 0.22$ & $12 \pm 2$ & $29 \pm 4$ \\
3000 & $1.74 \pm 0.23$ & $16 \pm 3$ & $44 \pm 6$ \\
\hline
\end{tabular}


Table 4. Dry mass (mg) of Scoloplos surface biodeposits per microcosm produced at $4 \mathrm{~d}$ intervals in Flax Pond sediments. Microcosm surface area $=50 \mathrm{~cm}^{2}$. Uncertainties are simple deviations from the mean of 2 treatments. $\mathrm{T}=15 \pm 1{ }^{\circ} \mathrm{C}$

\begin{tabular}{|c|c|c|c|c|c|c|c|c|c|}
\hline \multirow{2}{*}{$\begin{array}{l}\text { Worm density } \\
\text { (ind } \mathrm{m}^{-2} \text { ) }\end{array}$} & \multicolumn{9}{|c|}{ Sediment collection time (Days) } \\
\hline & 4 & 8 & 12 & 16 & 20 & 24 & 28 & 32 & 36 \\
\hline 400 & $\begin{array}{r}754 \\
+\quad 251\end{array}$ & $\begin{array}{r}582 \\
\pm \quad 322\end{array}$ & $\begin{array}{r}853 \\
\pm 153\end{array}$ & $\begin{array}{r}1185 \\
\pm \quad 255\end{array}$ & $\begin{array}{r}1644 \\
\pm \quad 32\end{array}$ & $\begin{array}{r}1623 \\
\pm 2\end{array}$ & $\begin{array}{r}1570 \\
\pm 3\end{array}$ & $\begin{array}{r}1579 \\
\pm 2\end{array}$ & $\begin{array}{r}1584 \\
\pm \quad 22\end{array}$ \\
\hline 800 & $\begin{array}{r}743 \\
\pm \quad 388\end{array}$ & $\begin{array}{r}952 \\
+\quad 241\end{array}$ & $\begin{array}{r}1167 \\
\pm \quad 333\end{array}$ & $\begin{array}{r}1390 \\
\pm 28\end{array}$ & $\begin{array}{r}1424 \\
\pm \quad 611\end{array}$ & $\begin{array}{r}1662 \\
\pm \quad 36\end{array}$ & $\begin{array}{r}1700 \\
\pm 2\end{array}$ & $\begin{array}{r}1662 \\
\pm 2\end{array}$ & $\begin{array}{r}1680 \\
\pm 96\end{array}$ \\
\hline 1600 & $\begin{array}{r}756 \\
\pm 122\end{array}$ & $\begin{array}{r}1001 \\
\pm 115\end{array}$ & $\begin{array}{r}1214 \\
\pm 10\end{array}$ & $\begin{array}{r}1534 \\
\pm 24\end{array}$ & $\begin{array}{r}1508 \\
\pm 9\end{array}$ & $\begin{array}{r}1742 \\
\pm 19\end{array}$ & $\begin{array}{r}1739 \\
\pm 19\end{array}$ & $\begin{array}{r}1735 \\
\pm 19\end{array}$ & $\begin{array}{r}1740 \\
\pm 85\end{array}$ \\
\hline 3000 & $\begin{array}{r}1964 \\
\pm 402\end{array}$ & $\begin{array}{r}2897 \\
\pm \quad 192\end{array}$ & $\begin{array}{r}4524 \\
\pm 257\end{array}$ & $\begin{array}{r}4382 \\
\pm 455\end{array}$ & $\begin{array}{r}5421 \\
\pm 512\end{array}$ & $\begin{array}{r}4221 \\
\pm \quad 859\end{array}$ & $\begin{array}{r}4140 \\
\pm 2\end{array}$ & $\begin{array}{r}4363 \\
\pm 8\end{array}$ & $\begin{array}{r}4580 \\
\pm 5\end{array}$ \\
\hline
\end{tabular}

$12.4 \pm 0.8$, and $13.0 \pm 0.2 \mathrm{~g}$ in the 400,800 , and 1600 ind $\mathrm{m}^{-2}$ microcosms respectively (Fig. 2). Although total mass of surface deposits increased significantly with worm abundance (1-way ANOVA), values in the 400 and 1600 ind $\mathrm{m}^{-2}$ treatments differed from the value in the 800 ind $\mathrm{m}^{-2}$ treatment by only 8 and $4 \%$ respectively.

Average rates of particle working by individual worms decreased in proportion to worm abundance in the 3 lowest-density treatments and were anomalously high in the highest-density treatment (Fig. 3). In the 3 lowest-density treatments, these average rates increased during the first 20 to $24 \mathrm{~d}$ (the rate of increase being most rapid at lower worm densities) and then leveled off. In the highest-density culture, individual particle working rate was anomalous inasmuch as the initial rate of increase was greater than might be expected by comparison with the lower-density treatments and because individual working rates reached a

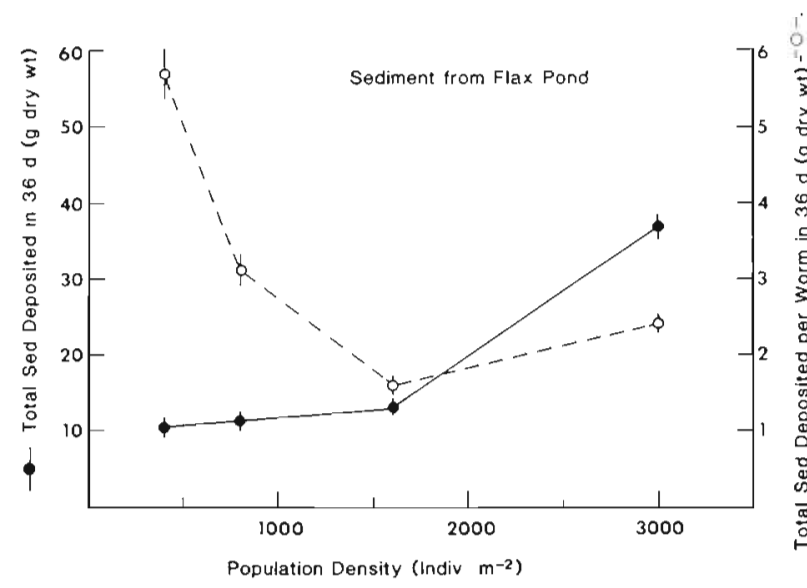

Fig. 2. Scoloplos spp. Total $36 \mathrm{~d}$ surface biodeposition per $50 \mathrm{~cm}^{2}$ by specimens cultured at 4 densities in Flax Pond sediment. Total deposition is given as total per $50 \mathrm{~cm}^{2}$ microcosm and as total per individual worm $\pm 1 \mathrm{SD} . \mathrm{T}=15 \pm 1^{\circ} \mathrm{C}$ plateau within $12 \mathrm{~d}$. Moreover, although the $36 \mathrm{~d}$ total deposition per worm was inversely related to worm abundance in the other treatments, the total for the highest-density treatment $(2.4 \pm 0.1 \mathrm{~g}$ dry sediment ind $^{-1}$ ) was slightly greater than that of the 1600 ind $\mathrm{m}^{-2}$ treatment $\left(1.6 \pm 0.1 \mathrm{~g}\right.$ dry sediment ind $\left.{ }^{-1}\right)$ (Fig. 2).

On a unit biomass basis, biodeposition rate decreased with increasing worm abundance up to 1600 ind $\mathrm{m}^{-2}$, and appeared to be anomalously high at 3000 ind $\mathrm{m}^{-2}$ (Table 3$)$. The initial rates of biodeposition per unit biomass (Day 4) decreased by consecutive factors of about 0.5 as worm density increased by consecutive factors of 2, except at the highest density (Table 3 , column 3). On the final day of the experiment, these rates in the 400 and 3000 ind $\mathrm{m}^{-2}$ microcosms were not significantly different from the initial rate of $46 \mathrm{~g}$ dry sediment ( $\mathrm{g}$ dry worm) ${ }^{-1} \mathrm{~d}^{-1}$ in the 400 ind $\mathrm{m}^{-2}$ treatments. Final rates in the 800 and 1600 ind $\mathrm{m}^{-2}$ treatments had increased greatly from their initial values but were significantly lower than final rates in the 400 and 3000 ind $\mathrm{m}^{-2}$ treatments (Table 3, column 4).

\section{DISCUSSION}

\section{Particle ingestion and biodeposition}

Under conditions in which availability of particles of ingestible size was not limiting, isothermal rates of particle biodeposition by Scoloplos were directly proportional to worm size. Because all surface deposition by Scoloplos results from egestion and because these worms do not appear to feed while burrowing (in laboratory microcosms), rates of biodeposition, egestion, and ingestion are essentially equivalent. In Lowes Cove sediments at $15^{\circ} \mathrm{C}$, initial and final rates of biodeposition by worms feeding in an essentially infinite field of ingestible particles were both $64 \mathrm{~g}$ (g dry 


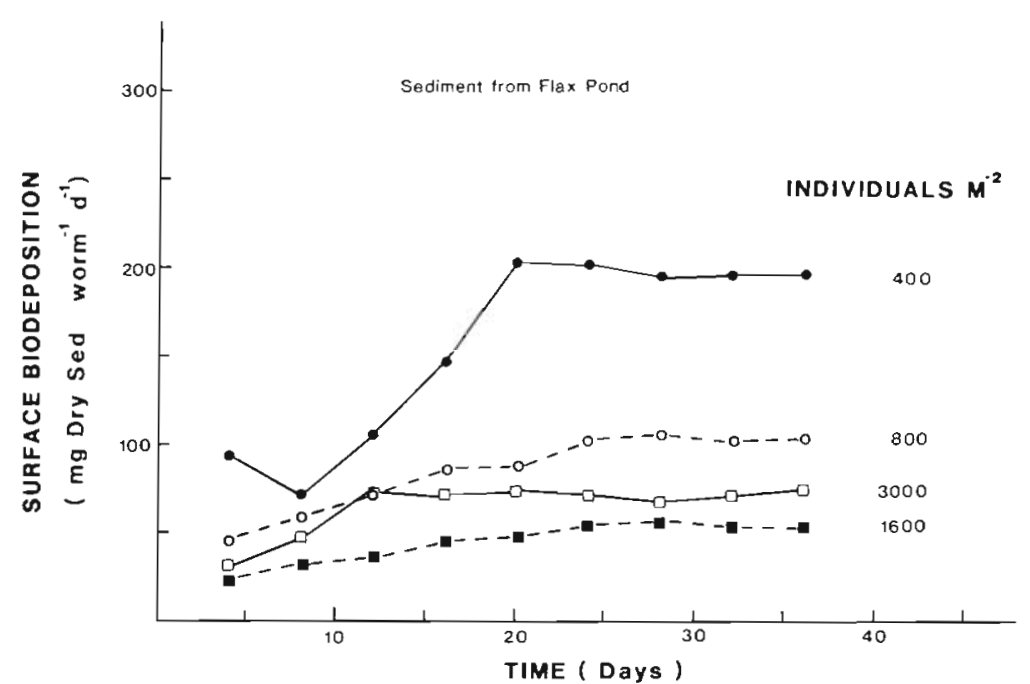

Fig. 3. Scoloplos spp. Average surface biodeposition rate in Flax Pond sediment over time and at different worm densities. Each point is the average of 2 determinations. $\mathrm{T}=15 \pm 1^{\circ} \mathrm{C}$ worm) $)^{-1} \mathrm{~d}^{-1}$ (Table 2). In Lowes Cove sediments at $21^{\circ} \mathrm{C}$ Scoloplos robustus ranging in size from 1.1 to 2.2 $\mathrm{g}$ dry $\mathrm{wt}$ ind $^{-1}$ and in density from 200 to 800 ind $^{-2}$ fed at rates ranging from 130 to $253 \mathrm{~g}$ sediment ind $^{-1}$ $\mathrm{d}^{-2}$; on a unit biomass basis, these rates converged to $120 \mathrm{~g}$ sediment (g dry worm) ${ }^{-1} \mathrm{~d}^{-1}$ (Rice 1986). As discussed below, even in Flax Pond sediments, where only $55 \%$ of the particles were of ingestible size (Table 1), biodeposition rate was proportional to worm biomass at the lowest worm density (Table 3). Similar relations between feeding rate and body size have been found for other deposit-feeding polychaetes (Nichols 1970, Whitlatch \& Weinberg 1982) and for polyspecific suites of deposit-feeding invertebrates (Cammen 1980a).

Rate of biodeposition by Scoloplos was strongly temperature-dependent, a well-documented phenomenon in other deposit-feeders (Gordon 1966, Hylleberg 1975, McCall \& Tevesz 1982). Assuming that the rates $r$ of $65 \mathrm{~g}$ sediment ( $\mathrm{g}$ worm) $)^{-1} \mathrm{~d}^{-1}$ at $17^{\circ} \mathrm{C}$ ('Table 2) and $120 \mathrm{~g}$ sediment (g worm) $)^{-1} \mathrm{~d}^{-1}$ at $21^{\circ} \mathrm{C}$ (Rice 1986) are related to absolute temperature $\mathrm{T}$ according to the Arrhenius rate law (Giese 1968),

$$
r(T)=A e^{-E a / R T}
$$

in which $\mathrm{A}=$ an apparent rate at infinite temperature and $\mathrm{R}=$ the gas constant $\left(1.987 \mathrm{cal} \mathrm{deg}^{-1} \mathrm{~mol}^{-1}\right)$, the apparent Arrhenius activation energy for Scoloplos feeding activity is $27 \pm 0.4 \mathrm{kcal} \mathrm{mol}^{-1}$. On this basis, the predicted feeding rate at $15^{\circ} \mathrm{C}$ is $45 \mathrm{~g}$ sediment ( $\mathrm{g}$ worm) $)^{-1} \mathrm{~d}^{-1}$ (Fig. 4), precisely the experimental value found for this temperature at the lowest worm density in Flax Pond sediment (Table 3). Interestingly, from 15 to $21^{\circ} \mathrm{C}$ the rate of sediment reworking by a freshwater conveyor-belt feeding oligochaete, Tubifex tubifex, increased by a factor of 2.5 (Wachs 1967), which com- pares with the factor of 2.7 found here for Scoloplos. However, the Arrhenius relation underpredicts feeding rate below $6^{\circ} \mathrm{C}$ by about $50 \%$ (our unpubl. data). Of course at some critical point above $21^{\circ} \mathrm{C}$, feeding activity by Scoloplos should begin to decline (McCall \& Tevesz 1982). Myers (1977) estimated that Scoloplos robustus ingested $0.06 \mathrm{~cm}^{3}$ particles ind $\mathrm{d}^{-1} \mathrm{~d}^{-1}$. Assuming an average particle density of $2.7 \mathrm{~g} \mathrm{~cm}^{-3}$ and an average worm dry biomass of $2 \mathrm{mg}$, this rate is about 80 $g$ dry sediment ( $g$ worm) $)^{-1} \mathrm{~d}^{-1}$. Assuming further from his data that this value corresponds to an average temperature of $18^{\circ} \mathrm{C}$ (the reported range was 10 to $26^{\circ} \mathrm{C}$ ), there is good agreement with the rate of $75 \mathrm{~g} \mathrm{dry}$ sediment ( $\mathrm{g}$ worm) $)^{-1} \mathrm{~d}^{-1}$ predicted from the Arrhenius equation above.

Although feeding rate per unit biomass at $15^{\circ} \mathrm{C}$ in the lowest density culture in Flax Pond sediment was as expected after adjusting for temperature differences, rates at higher worm densities were lower. This observation, coupled with the observations that (1) worms grew significantly more at lower densities (Table 3) and (2) the total amount of sediment deposited in $36 \mathrm{~d}$ differed by only a few percent among the 3 lower density treatments, indicates that there was competition for preferred particles. At these 3 low worm densities, biodeposition per individual had an almost perfect reciprocal relation (by consecutive factors of 2 ) with worm density throughout the experiment. The existence of this inverse proportionality as early as Day 4 suggests that individual foraging areas were established soon after worms burrowed in the microaquaria. Assuming an average foraging radius of $3 \mathrm{~cm}$, the estimated foraging area of an individual worm should be about $28 \mathrm{~cm}^{2}$. Approximating this area as $25 \mathrm{~cm}^{2}$ and recalling that microcosm area was $50 \mathrm{~cm}^{2}, 2$ worms could forage with no overlap; at densities of 4 and 8 worms microcosm $\mathrm{m}^{-1}$, average foraging activity in any 
part of the microcosm should be greater by factors of 2 and 4 respectively, as reflected in relative values of individual biodeposition rates (Fig. 3). If particle availability were not limiting at worm densities greater than $400 \mathrm{~m}^{-2}$, this proportionality of rates should exist on a unit biomass basis rather than on a per individual basis. However, as indicated by rates of biodeposition per unit biomass, feeding interference established early in the experiment diminished with time; low rates (g worm) $)^{-1}$ gradually approached the expected value of $45 \mathrm{~g}$ sediment (g worm) $)^{-1} \mathrm{~d}^{-1}$ (Table 3).

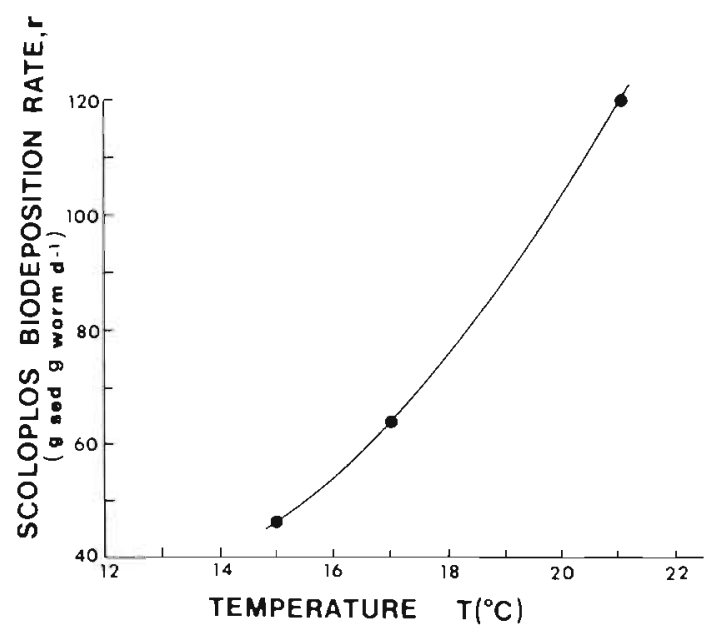

Fig. 4. Scoloplos spp. Estimated rate of surface biodeposition as a function of temperature. Data are for conditions in which availability of ingestible particles does not limit ingestion rate. The curve is the best fit to the Arrhenius rate relation

$$
\frac{r\left(T_{1}\right)}{r\left(T_{2}\right)}=\exp \left(\frac{E_{a}}{R}\left[\frac{1}{T_{2}}-\frac{1}{T_{1}}\right]\right)
$$

where $T_{1}$ and $T_{2}=$ any 2 of the 3 temperatures in degrees Kelvin; $R$ is the gas constant; $E_{a}=27 \pm 0.4 \mathrm{kcal} \mathrm{mol}^{-1}$, the apparent Arrhenius activation energy

By the same line of reasoning as above, one might expect that at the highest density of 3000 ind $\mathrm{m}^{-2}$ the rate per individual would be lower than the rate at 1600 ind $\mathrm{m}^{-2}$ by a factor of 0.53 ; instead it was higher by a factor of 1.4 (Fig. 3). Worms at the highest density apparently fed on a larger size-range of particles and produced in $36 \mathrm{~d}$ about 2.7 times more biodeposits than worms at 1600 ind $\mathrm{m}^{-2}$ (Fig. 2). Nevertheless, final individual biomass was the same at both densities, implying at least one of the following:(1) that worms at higher density fed on a larger reservoir of particles of lower average nutritional value; (2) that worms at higher density suffered a proportionally greater metabolic loss. Because particle size distribution and organic composition of biodeposits were not measured in this experiment, it is formally impossible to ascertain which mechanism was operative. In both Lowes
Cove and Flax Pond sediments worms in the 1.6 to 2.2 $\mathrm{mg}$ dry weight range ingested particles roughly in proportion to their abundance in the conveyor-belt zone of Lowes Cove, i. e. $30 \% 250$ to $64 \mu \mathrm{m}$ and $70 \%$ $<63 \mu \mathrm{m}$ (Table 1). Although Scoloplos feeding must have followed the RPD as it migrated to depth (see below) where more small particles would be available, a growing lag deposit of 250 to $63 \mu \mathrm{m}$ particles would have to form at and just above the principal feeding depth. In such an environment of diluted resources, worms at the highest density in Flax Pond sediment probably had to feed at the maximum rate of ca $45 \mathrm{~g}$ sediment ( $g$ worm $)^{-1} \mathrm{~d}^{-1}$ to avoid starvation. At high grazing pressure induced by higher worm density, feeding must have shifted disproportionately toward the 250 to $63 \mu \mathrm{m}$ fraction. Because the thickness of the RPD appeared to be about the same at all worm densities, the concomitant increase in individual feeding rate in Flax Pond sediment is consistent with a compensatory feeding strategy (Gordon 1966, Tenore \& Gopalan 1974, Conover 1978, Cammen 1980a).

Foraging competition in our microaquaria was prompted in part by the affinity of Scoloplos for feeding at the RPD, a common characteristic of marine conveyor-belt feeders (Rhoads 1974, Rhoads \& Boyer 1982, McCall \& Tevesz 1982). During our first attempts at culturing Scoloplos in the aquarium, we noted that it was virtually impossible to maintain healthy worms in thin layers of buff-colored sediments; even with regular food additions to the cultures, worms would either swim away or else remain in the sediment and lose weight. As seen through the translucent walls of the microaquaria in the present study, within a few days after the addition of worms, the RPD migrated to and remained at a depth of about 2 to $2.5 \mathrm{~cm}$ below the sediment surface and appeared to be only a few $\mathrm{mm}$ thick. Although there were far more particles of ingestible size in each microaquarium than could possibly be ingested by the worms in $36 \mathrm{~d}$, only a small fraction of these were at the RPD feeding zone at any given time.

The amelioration of feeding interference over time probably reflects the gradual development of spatially distinct feeding sites. During the set up of the experiment, some worms in the highest density microaquaria would crawl out on the sediment surface and reburrow at another site, perhaps to avoid contact with another individual. Also the large decrease over time in feeding rate uncertainties between duplicate microcosms in this experiment (Table 4) suggests a gradual adjustment of spatial domains of feeding. Given sufficient time, individuals are able to distribute themselves horizontally and vertically so that interference is eliminated or minimized. For example, in an incubated core from Lowes Cove containing more than 2800 Scoloplos $\mathrm{m}^{-2}$, the observed rate of sediment reworking was 
Table 5. Estimates of growth parameters for Scoloplos spp. grown in experimental sediments from Lowes Cove, Maine, Calculations based on partitioning of organic carbon. $T=17 \pm 1^{\circ} \mathrm{C}$

\begin{tabular}{|c|c|c|}
\hline Parameter description & Estimated parameter value & Source \\
\hline 1. Total dry mass of sediment ingested in $16 \mathrm{~d}$ & $1292 \mathrm{mg}$ sed $\mathrm{ind}^{-1}$ & Table 2 \\
\hline $\begin{array}{l}\text { 2. Average POC content of ambient } \\
\text { experimental sediment } \\
\text { (average over particle size distribution) }\end{array}$ & $0.83 \% \mathrm{C}$ & Table 1 \\
\hline 3. Total POC deposited in $16 \mathrm{~d}$ & $11.5 \mathrm{mg} \mathrm{C} \mathrm{ind} \mathrm{d}^{-1}$ & Table 2 \\
\hline $\begin{array}{l}\text { 4. Total POC ingested in } 16 \mathrm{~d} \text { assuming } \\
\text { particle selectivity of } \\
1.7 \text { to } 2.2 \mathrm{mg} \text { worms }\end{array}$ & $10.7 \mathrm{mg} \mathrm{C}$ ind $^{-1}$ & Items $1 \& 2$ \\
\hline $\begin{array}{l}\text { 5. Carbon assimilation efficiency (AE) } \\
\text { during last } 4 \mathrm{~d}\end{array}$ & $24 \%$ & $\begin{array}{l}\% \mathrm{C} \text { in egestate (Table } 2 \text { ) } \\
\text { and item } 2\end{array}$ \\
\hline 6. Total POC ingested assuming $24 \% \mathrm{AE}$ & $15.1 \mathrm{mg} \mathrm{C}$ ind $^{-1}$ & Items $3 \& 5$ \\
\hline 7. Average $\%$ POC in sediment ingested in $16 \mathrm{~d}$ & $1.17 \% \mathrm{C}$ & Items $1 \& 6$ \\
\hline 8. Net worm $C$ produced in $16 \mathrm{~d}$ & $0.36 \mathrm{mg} \mathrm{C} \mathrm{ind} \mathrm{in}^{-1}$ & $\begin{array}{l}\text { Table } 2 \text {; assumes } 50 \% \text { of } \\
\text { worm biomass is C }\end{array}$ \\
\hline 9. Gross growth efficiency & $2.4 \%$ & Items $6 \& 8$ \\
\hline 10. Total POC assimilated in $16 \mathrm{~d}$ & 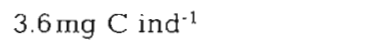 & Items $3 \& 6$ \\
\hline $\begin{array}{l}\text { 11. Minimum fraction of assimilated } \\
\mathrm{C} \text { also incorporated into worm biomass }\end{array}$ & $10 \%$ & Items $8 \& 10$ \\
\hline
\end{tabular}

equal to the rate expected on the basis of measured biodeposition rates per unit biomass by worms cultured at the same temperature $\left(21^{\circ} \mathrm{C}\right)$ at densities of 1 to 4 individuals per $50 \mathrm{~cm}^{2}$ microcosm (Rice 1986). This observation suggests a complete absence of feeding interference in Lowes Cove, where the RPD is a broad irregular zone distributed over a vertical range of about $3 \mathrm{~cm}$.

\section{Worm growth and nutrition}

Scoloplos is capable of rapid growth in unenriched sediments. Single worms in experimental Lowes Cove sediment grew at a weight-specific rate between 5 and $9 \% \mathrm{~d}^{-1}$. Assuming that the shape of the feeding curve for the 400 ind $\mathrm{m}^{-2}$ microcosm of Flax Pond sediment (Fig. 3) reflects initial worm growth, those worms also had a weight-specific growth rate of $5 \% \mathrm{~d}^{-1}$. Individuals larger than $3 \mathrm{mg}$ dry weight are rare in Lowes Cove but were found at the 2 lowest worm densities in our experiments with Flax Pond sediments.

The large decrease in organic content of surface biodeposits during the $16 \mathrm{~d}$ experiment with Lowes Cove sediment (Table 2) indicates that Scoloplos initially selected particles of high organic content and superficially supports both optimal foraging (Taghon et al. 1978, Taghon 1981, Taghon \& Jumars 1984) and compensatory feeding (Cammen 1980a) strategies for these worms. It is unlikely that such a large decrease in
$\% \mathrm{C}$ in biodeposits resulted from decomposition of ambient sedimentary organic matter during the experiment. Although more organic matter might be removed from sediment during passage through a longer gut (Bianchi \& Levinton 1981), differences in sizes of initial and final worms in this experiment were probably too small to differentially affect carbon removal. If the information on either bulk egestion rate or growth were not available, the argument for optimal foraging as envisioned by Taghon et al. (1978) would be compelling inasmuch as smaller, organic-rich particles were selected first. Similarly, without growth data and the knowlegde that isothermal feeding rate is proportional to individual biomass, the increase in feeding rate concomitant with decreasing organic content in egested particles could also be used to support a compensatory feeding paradigm. However, in this experiment worms were initially quite small (about half the size of the worms in the inoculum of the Flax Pond sediment experiment). Particle size selection by these worms was necessarily restricted by anatomical and mechanical factors (Whitlatch \& Weinberg 1982), so that smaller individuals obligatorily fed on finer, richer material. Analogously, small Macoma balthica feed more selectively on particles of a smaller average size than do larger individuals (Gilbert 1977). Although explicit measurements were not made in this study, casual observation of the biodeposits of worms of different sizes leaves no doubt that the size of ingested particles increases as these worms grow. 
From the organic carbon contents of ambient ingestible Lowes Cove sediment and of biodeposits produced from Day 12 to Day 16, one can estimate that approximately $24 \%$ of the ingested organic carbon was assimilated (Table 5). Data from the last $4 \mathrm{~d}$ were used to make this estimate because by then the worms had grown to a size for which particle size selectivity and carbon content could be estimated (Table 1). Over $16 \mathrm{~d}$, each individual egested about $11.5 \mathrm{mg}$ POC and, for an assimilation efficiency of $24 \%$, must have ingested $15.1 \mathrm{mg}$ POC. If one were to assume that small worms earlier in the experiment ingested the same size spectrum of particles as larger worms at the end, the total ingestion per individual would be about $10.7 \mathrm{mg} C$ (Table 5); because error propagation yields a precision of about $18 \%$ for this calculation, this value is not significantly different from the $11.5 \mathrm{mg}$ egestion value. As discussed above, during worm growth there must have been concomitant changes in the average size (increase) and organic content (decrease) of ingested particles.

In Lowes Cove sediment approximately $2.4 \%$ of the ingested organic carbon or $10 \%$ of the assimilated organic carbon was incorporated into Scoloplos biomass (Table 5, Fig. 5). A gross growth efficiency (GGE) of $2.4 \%$ is low compared to values found in experimental systems in which marine invertebrates were fed well-controlled diets of highly assimilable detrital source materials (Tenore 1983, and earlier work cited therein). If the assimilation efficiency calculated above were $100 \%$ too high (i. e. $\mathrm{AE}=12 \%$ ), the net production:assimilation ratio would be about $22 \%$, but GGE based on total sedimentary particulate organic carbon (POC) would still be quite low $(2.7 \%)$. This value is not surprising, however, inasmuch as most particulate organic matter (POM) in the benthic environment is refractory (Parsons et al. 1977). POM depth profiles of sediment cores taken from the site where experimental sediment was collected indicated that POM decreases exponentially with depth from a

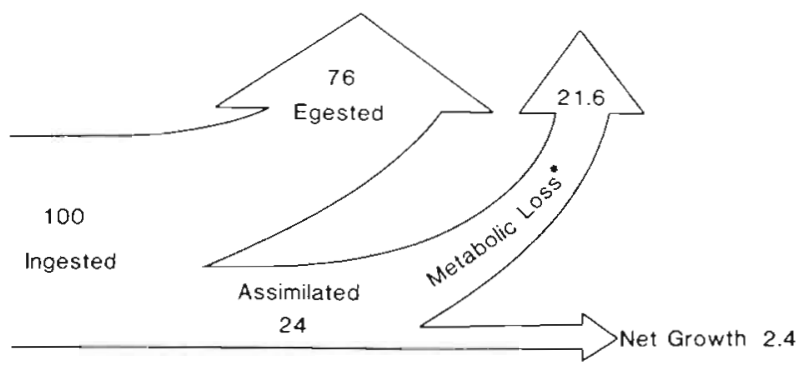

Fig. 5. Scoloplos spp. Estimated partitioning of Particulate Organic Carbon by specimens growing in sediment from Lowes Cove. $\mathrm{T}=17 \pm 1^{\circ} \mathrm{C}$. ' Metabolic loss includes mucus as well as respired and excreted carbon surface value of $3.9 \%$ to an asymptotic value of ca $2.3 \%$ in the 10 to $20 \mathrm{~cm}$ depth range. In the 0 to $10 \mathrm{~cm}$ interval (material used in experiments), $29 \%$ of the total POM was in excess of the asymptotic (refractory) background. Assuming a steady-state flux of POM across the sediment surface at the sediment collection site, this value should approximate the metabolizable fraction of total POM or POC. Then based on available carbon (actually, available calories), GGE would be $8.3 \%$.

Gross growth efficiency is substantially greater when calculations are made on the basis of particulate organic nitrogen (PON). Assuming that the average organic nitrogen content of ingested particles was $0.113 \%$ (Table 1 ) and that $8 \%$ of worm dry biomass is nitrogen, GGE based on total sedimentary PON was $4.0 \%$. PON depth profiles from the sediment collection site decrease from a surface value of $0.14 \%$ to an asymptotic value of $0.11 \%$ within the top $5 \mathrm{~cm}$. Using the same argument as above for POM/POC, about $6 \%$ of the PON in the experimental sediment was metabolizable. Therefore, GGE based on available nitrogen was about $63 \%$. Trophic transfer efficiencies as high as $88 \%$ based on nitrogen have been reported recently for experimental populations of Capitella capitata (Type 1) feeding on highly assimilable foods (Tenore \& Chesney 1985). On the basis of earlier studies, Tenore $(1981,1983)$ has argued that such calculations should be made on the basis of nitrogen because detritivores and deposit-feeders are commonly nitrogen-limited (Tenore \& Chesney 1985) Detritus used in Tenore's experiments were wellleached but non-humified substrates. Because sedimentary PON is mostly refractory and unavailable (Rice 1982), total nitrogen in Tenore's well-controlled systems is equivalent to available nitrogen in studies with natural sediment. Keeping this in mind would facilitate the comparison of results of basic nutritional studies of deposit-feeders (e. g. Tenore 1977, 1981, 1983) with in vitro feeding studies carried out with near-natural or substantially modified sediments (e. g. Lopez \& Levinton 1978, Lopez \& Cheng 1983, Bianchi \& Levinton 1984).

From the Flax Pond sediment experiment, one can use data from the 1600 ind $\mathrm{m}^{-2}$ microcosms to estimate the detrital nitrogen maintenance ration (Tenore 1983 Tenore \& Chesney 1985) of Scoloplos. In this treatment worm biomass changed insignificantly in $36 \mathrm{~d}$ (Fig. 1) Assuming that eight $2 \mathrm{mg}$ worms in these microcosms ingested a total of 13 dry g of sediment (Fig. 2) containing $0.32 \% \mathrm{~N}$ (Table 1 ), the total nitrogen maintenance ration was $72 \pm 7 \mathrm{mg} \mathrm{N}(\mathrm{g} \text { worm })^{-1} \mathrm{~d}^{-1}$. At $20^{\circ} \mathrm{C}$, this would be $160 \mathrm{mg} \mathrm{N}$ (g worm) $)^{-1} \mathrm{~d}^{-1}$ (Fig. 4). For Capitella capitata cultured at $20^{\circ} \mathrm{C}$ on substrates from which as much as $100 \%$ of the nitrogen is assimilable, 
the available nitrogen maintenance ration is about 78 mg $\mathrm{N}$ (g worm $)^{-1} \mathrm{~d}^{-1}$ or approximately $6.2 \mathrm{mg}$ available $N$ (g worm) $)^{-1} d^{-1}$ (Tenore \& Chesney 1985). Assuming that $C$. capitata and Scoloplos have identical organic nitrogen maintenance requirements per unit biomass, then for Scoloplos $160 \mathrm{mg}$ of Flax Pond detrital nitrogen and $6.2 \mathrm{mg}$ of available nitrogen shoud be nutritionally equivalent. We estimate then that approximately $4 \%$ of the PON in Flax Pond experimental sediment was nutritionally available to Scoloplos. Inasmuch as detrital nitrogen tends to build up in the recalcitrant fraction of old sedimentary organic matter (Rice 1982, Rice \& Hanson 1984), it is not surprising that this percentage is so low. On this basis, in the 400 and 800 ind $\mathrm{m}^{-2}$ microcosms respectively, roughly 16 and $9 \mathrm{mg}$ available $\mathrm{N}$ (g worm) $)^{-1} \mathrm{~d}^{-1}$ were ingested, sufficient for somatic and, in 2 instances, reproductive growth (Fig. 1).

In Flax Pond sediment microcosms, microbes may have provided all or most of the organic nitrogen required by Scoloplos. Assuming that (1) the average bacterial abundance in Flax Pond sediment is $5 \times 10^{9}$ cells (g dry sediment) ${ }^{-1}$ (Levinton et al, 1984), (2) the dry biomass of an individual bacterium is twice its carbon biomass of $2 \times 10^{13} \mathrm{~g} \mathrm{C}$ cell $^{-1}$ (Luria 1960), and (3) $7 \%$ of dry bacterial biomass is nitrogen, then $4 \%$ of the PON in these experimental sediments was in bacteria. Based on the foregoing argument, bacteria could account for all of the metabolizable PON. Because nitrogen is incorporated into worm biomass with high efficiency and because the organic carbon:nitrogen ratios in bacterial and worm biomass are similar, it is clear that a supplementary detrital carbon source must have been utilized to meet energetic requirements of Scoloplos. For every mole of carbon in net growth, as much as 9 moles of carbon may have been expended as metabolic loss (Fig. 5). Similarly, even if microbes account for all of the available nitrogen, nonliving detrital material must have contributed significantly to the carbon requirements of Nereis succinea (Cammen 1980b).

The strong dependence of maximum isothermal feeding rate upon individual biomass of Scoloplos suggests that these worms feed discriminately on particles of a particular size range (determined by worm morphology and size) whenever possible and that particle selection is not affected by food quality per se. For example, the data in Fig. 1 and 2 suggest that worms did not alter their preferred particle size ingestion except in the highest density culture. Worms in the 3000 ind $\mathrm{m}^{-2}$ culture were clearly pressed early in the experiment to consume more sediment to avoid losing biomass. Collectively, these observations also suggest that if Scoloplos is unable to meet maintenance ration by ingesting the normal size spectrum of particles, a shift in average size of ingested particles may occur. The worms may then feed compensatorily up to the maximum realizable rate for a worm of a particular size.

Acknowledgements. We thank J. Bianchi and S. Whitlow for technical assistance. Dr L. M. Mayer provided field laboratory space at the I. C. Darling Center, University of Maine at Orono. We also thank Dr. L. Cammen and 3 anonymous reviewers for helpful comments and criticisms. This research was supported by funds from the National Oceanic and Atmospheric Administration (Award NA 81AA-D-0099) and from National Science Foundation grant numbers OCE8310178 and OCE-8442759. Contribution No. 179 from the I. C. Darling Center, University of Maine at Orono

\section{LITERATURE CITED}

Bevington, P. R. (1969). Data reduction and error analysis for the physical sciences, McGraw-Hill Co., New York

Bianchi, T. S., Levinton, J. S. (1981). Nutrition and food limitation of deposit-feeders. II. Differential effects of Hydrobia totteni and Ilyanassa obsoleta on the microbial community. J. mar. Res. 39: 547-556

Bianchi, T. S., Levinton, J. S. (1984). The importance of microalgae, bacteria, and particulate organic matter in the somatic growth of Hydrobia totteni (Gastropoda). J. mar. Res. 42: 431-443

Cammen, L. M. (1980a). Ingestion rate: An empirical model for aquatic deposit feeders and detritivores. Oecologia (Berl.) 44: 303-310

Cammen, L. M. (1980b). The significance of microbial carbon in the nutrition of the deposit-feeding polychaete Nereis succinea. Mar. Biol. 61: 9-20

Conover, R. J. (1978). Transformation of organic matter. In: Kinne, O. (ed.) Marine ecology, Vol. IV, Dynamics. John Wiley and Sons, Chichester, p. 221-499

Dobbs, F. C., Whitlatch, R. B. (1982). Aspects of depositfeeding by the polychaete Clymenella torquata. Ophelia 21: $159-166$

Giese, A. C. (1968). Cell physiology, W. B. Saunders Co., Philadelphia

Gilbert, M. A. (1977). The behavior and functional morphology of deposit feeding in Macoma balthica (Linne, 1758), in New England. J. mollusc. Stud. 43: 18-27

Gordon, D. C. (1966). The effects of the deposit feeding polychaete Pectinaria gouldi in the intertidal sediments of Barnstable Harbor Limnol. Oceanogr 11: 327-332

Hylleberg, J. (1975). Selective feeding by Abarenicola pacifica with selective notes on Abarenicola vagabunda and a concept of gardening in lugworms. Ophelia 14: $113-137$

Levinton, J. S., Bianchi, T S., Stewart, S. (1984). What is the role of particulate organic matter in benthic invertebrate nutrition? Bull. mar. Sci. 35: 270-282

Lopez, G. R., Cheng, I.-J. (1983). Synoptic measurements of ingestion rate, ingestion selectivity, and absorption efficiency of natural foods in the deposit-feeding molluscs Nucula annulata (Bivalvia) and Hydrobia totteni (Gastropoda). Mar. Ecol. Prog. Ser 11: 55-62

Lopez, G. R., Levinton, J. S. (1978). The availability of microorganisms attached to sediment particles as food for Hydrobia ventrosa (Montagu) (Gastropoda: Prosobranchia). Oecologia (Berl.) 32: 263-275 
Lopez, G. R., Levinton, J. S. (1987). Ecology of deposit-feeding animals in marine sediments. $Q$. Rev. Biol. (in press)

Luria, S. E. (1960). The bacterial protoplasm: composition and organization. In: Gunsalus, I. C. (ed.) The bacteria, Vol. 1. Academic Press, New York

McCall, P. L., Tevesz, M. J. S. (1982). The effects of benthos on physical propeties of freshwater sediments. In : McCall, P. L., Tevesz, M. J. S. (ed.) Animal-sediment relations. Plenum Press, New York, p. 105-168

Myers, A. C. (1977). Sediment processing in a marine subtidal sandy bottom community: I. Physical aspects. J. mar. Res. 35: 609-632

Nichols, F. H. (1970). Benthic polychaete assemblages and their relationship to the sediment in Port Madison, Washington. Mar. Biol. 6: 48-57

Parsons, T. R., Takahashi, M., Hargrave, B. (1977). Biological oceanographic processes. 2nd edn. Pergamon, London

Rhoads, D. C. (1974). Organism-sediment relations on the muddy floor. Oceanogr. mar. Biol. A. Rev. 12: 263-300

Rhoads, D. C., Boyer, L. F. (1982). The effects of marine benthos on physical properties of sediments: A successional perspective. In: McCall, P. L., Tevesz, M. J. S. (ed.), Animal-sediment relations. Plenum Press, New York, p. $3-43$

Rice, D. L. (1982). The detritus nitrogen problem: New observations and perspectives from organic geochemistry. Mar Ecol. Prog. Ser, 9: 153-162

Rice, D. L. (1986). Early diagenesis in bioadvective sediments: Relationships between the diagenesis of beryllium-7, sediment reworking rates, and the abundance of conveyor-belt deposit-feeders. J. mar. Res. 44: 149-184

Rice, D. L., Hanson, R. B. (1984). A kinetic model for detritus nitrogen: Role of the associated bacteria in nitrogen accumulation. Bull. mar. Sci. 35 (3): 326-340

Rice, D. L., Whitlow, S. I. (1985a). Early diagensis of transition metals: A study of metal partitioning between macrofaunal populations and shallow sediments. In: The fate and effects of pollutants, Proceedings of a Maryland Seagrant Symposium, Maryland Seagrant Programm, Univ. of Maryland Press, College Park, p. 21-30

Rice, D. L., Whitlow, S. I. (1985b). Diagenesis of transition metals in bioadvective marine sediments. In: Lekkas, T. D. (ed.) Heavy metais in the environment, Vol. 2, Proceedings of the 5th International Conference, Athens, Greece, CEP Consultants Ltd., Edinburgh, p. 353-355

Taghon, G. L. (1981). Beyond selection: Optimal ingestion rate as a function of food value. Am. Nat. 118: 202-214

Taghon, G. L., Jumars, P. L. (1984). Variable ingestion rate and its role in optimal foraging behavior of marine deposit feeders. Ecology 65: 549-558

Taghon, G. L., Self, R. F. L., Jumars, P. A. (1978). Predicting particle selection by deposit feeders: A model and its implications. Limnol. Oceanogr. 23: 752-759

Tenore, K. R. (1977). Growth of Capitella capitata cultured on various levels of detritus derived from various sources. Limnol. Oceanogr. 22: 936-941

Tenore, K. R. (1981). Organic nitrogen and caloric content of detritus. 1. Utilization by the deposit-feeding polychaete Capitella capitata. Estuar. coast. Shelf Sci. 12: 39-47

Tenore, K. R. (1983). Organic nitrogen and caloric content of detritus. 3. Effect on growth of a deposit-feeding polychaete, Capitella capitata. Estuar. coast. Shelf. Sci. 17: 733-742

Tenore, K. R., Chesney, E. J. (1985). The effects of interaction of rate of food supply and population density on the bioenergetics of the opportunistic polychaete, Capitella capitata (type I). Limnol. Oceanogr. 30: 1188-1195

Tenore, K. R., Gopalan, U. K. (1974). Food chain dynamics of the polychaete, Nereis virens, cultured on animal tissue and detritus. J. Fish. Res. Bd Can. 31: 1675-1678

Wachs, B. (1967). Die Oligochaeten-Fauna der Fleißgewässer unter besonderer Berücksichtigung der Beziehungen zwischen der Tubificiden-Besiedlung und dem Substrat. Arch. Hydrobiol. 63: 310-386

Whitlatch, R. B., Weinberg, J. R. (1982). Factors influencing particle selection and feeding rate in the polychaete Cistenides (Pectinaria) gouldii. Mar. Biol. 71: 33-40

Yingst, J. Y., Rhoads, D. C. (1980). The role of bioturbation in the enhancement of bacterial growth rates in marine sediments. In: Tenore, K. R., Coull, B. C (ed.) Marine benthic dynamics. University of South Carolina Press, Columbia, p. $407-421$ 